\title{
Chromosomal abnormalities in liver cell dysplasia detected by comparative genomic hybridisation
}

\author{
A Marchio, B Terris, M Meddeb, P Pineau, A Duverger, P Tiollais, A Bernheim, A Dejean
}

Unité de

Recombinaison et

Expression Génétique, INSERM U163, Institut Pasteur, 75724 Paris,

France

A Marchio

P Pineau

$P$ Tiollais

A Dejean

Laboratoire

d'Anatomie

Pathologique, Hôpital

Cochin, 75014 Paris,

France

B Terris

Laboratoire de

Cytogénétique et

Génétique

Oncologiques (URA

1967 CNRS), Institut

Gustave Roussy, 94800

Villejuif, France

$M$ Meddeb

A Duverger

A Bernheim

Correspondence to:

Dr Marchio, UREG, Institut

Pasteur, 28 rue du Docteur

Roux, 752724 Paris Cedex

15, France

amarchio@pasteur.fr

Accepted for publication

27 March 2001

\begin{abstract}
BackgroundlAim-The pathogenetic relation between liver cell dysplasia and hepatocellular carcinoma (HCC) is poorly understood. The aim of this study was to determine whether there is a genetic link between liver cell dysplasia and HCC that could support the role of dysplasia as a tumour precursor lesion.

Methods-Microdissection from paraffin wax embedded sections and degenerate oligonucleotide primed polymerase chain reaction (DOP-PCR) were combined to analyse chromosomal imbalances by comparative genomic hybridisation (CGH) in nine HCCs and nodules containing liver cell dysplasia and cirrhosis adjacent to the tumours. Seven cases of large cell changes (LCC) and three cases of small cell changes (SCC) were analysed. The genetic abnormalities detected in liver cell dysplasia were then compared with those present in the corresponding HCC.

Results-No abnormalities were detected in LCC and cirrhotic nodules, arguing against the preneoplasic nature of these cell foci. In contrast, a subset of chromosomal alterations present in HCCs was found in the adjacent SCC.

Conclusions-These findings support the preneoplastic status of SCC in human hepatocarcinogenesis.

(F Clin Pathol: Mol Pathol 2001;54:270-274)
\end{abstract}

Keywords: comparative genomic hybridisation; hepatocellular carcinoma; liver cell dysplasia

Hepatocellular carcinoma (HCC) is one of the most common human malignancies, yet the molecular mechanisms involved in its development and the preneoplastic cellular component still remain obscure. A characterisation of the genetic events that accompany the progression of precursor lesions towards fully malignant tumours may be useful for early detection, in addition to preventive treatment. In liver, two types of lesion are usually recognised as preneoplastic. The first consists of nodular lesions called dysplastic nodules, ${ }^{1}$ and several lines of evidence suggest that they pose a risk for malignant transformation. ${ }^{2-5}$ However, opinions on the histological severity attributed to such lesions vary widely among pathologists. ${ }^{6}$ The second type of preneoplastic lesion, referred to as liver cell dysplasia, is defined by the presence of atypical hepatocytes. According to most authors, liver cell dysplasia can be divided into two subtypes: large cell changes (LCC) and small cell changes (SCC). ${ }^{78}$ The frequent association of such dysplastic foci with HCC arising in cirrhotic livers suggests a preneoplastic role for liver cell dysplasia in the sequence driving cirrhosis towards HCC. ${ }^{9-11}$ Although two large prospective studies have suggested that LCC is the most important risk factor for HCC, ${ }^{12}{ }^{13}$ its premalignant nature is still controversial. ${ }^{13-16}$ To date, there are no genetic reports supporting a direct transition from liver cell dysplasia to HCC.

Recently, the genetic analysis of morphologically defined cell foci from tissue sections has become feasible through the use of microdissection approaches. Comparative genomic hybridisation (CGH) is a powerful molecular cytogenetics tool that permits whole genome screening for quantitative genomic abnormalities without the requirement for an initial tissue culture step. In our study, we combined microdissection and $\mathrm{CGH}$ to identify chromosomal aberrations in cirrhosis, liver cell dysplasia, and HCC in nine liver resections. Our aim was to identify a possible genetic link supporting the role of liver cell dysplasia as a precursor lesion of HCC.

\section{Materials and methods}

PATIENTS AND TISSUE SAMPLES

Formalin fixed liver tissue specimens were obtained from nine patients who underwent complete resection for HCC in the surgical department of Beaujon Hospital (Clichy, France). All of the tumours developed on liver cirrhosis and contained dysplastic foci. By definition, these dysplastic foci are not macroscopically recognisable and are smaller than $1 \mathrm{~mm}$ in diameter. Such a pattern distinguished them from the dysplastic nodules. ${ }^{1}$ The aetiology of cirrhosis was viral in five patients (four hepatitis $\mathrm{B}$ virus (HBV), one hepatitis $\mathrm{C}$ virus $(\mathrm{HCV})$ ), alcoholic in three, and haemochromatosic in one. According to Edmonson and Steiner's criteria, ${ }^{17}$ six HCCs were grade II (moderately differentiated) and three were grade III (poorly differentiated). As described by Anthony et $a l,{ }^{7}$ LCC was identified in seven patients as hepatocytes larger than normal with enlarged, hyperchromatic, often pleiomorphic nuclei and prominent nucleoli. LCC were composed either of few scattered cells within a cirrhotic nodule or, alternatively, as big foci occupying a whole nodule. ${ }^{8}$ SCC was identified by the criteria of Watanabe et al as small hepatocytes with nuclear atypia forming hepatic plates two to three cells in thickness and arranged in compact areas. ${ }^{8}$ The reticulin framework was preserved and architectural atypia was not sufficient to allow a definite diagnosis of HCC. All these dysplastic changes were encountered on systematic specimens performed in non-tumoral liver. No macronodules were present and no reactive fibrosis at the periphery of these dysplastic foci was observed. 
In summary, the three alcoholic cases were associated with LCC (E1, E4, E6), the haemochromatosic patient with both LCC and SCC (E2), the HCV infected patient with SCC (E8), three of the HBV infected patients with LCC (E5, E7, E9), and one HBV infected patient with SCC (E3).

MICRODISSECTION AND DNA EXTRACTION

For each case, appropriate tissue blocks were selected and serial sections, $7 \mu \mathrm{m}$ in thickness, were dewaxed and stained either by haematoxylin and eosin for histological analysis or by Giemsa for microdissection. To avoid contamination during microdissection, two slides were selected for each case: one containing the tumour and the second both cirrhosis and dysplastic foci. Areas of interest, containing approximately 30 cells, were microdissected with a sterile extended pipette of $60 \mu \mathrm{m}$ in diameter under an inverted microscope using either $\times 40$ or $\times 100$ magnification. Typical examples of LCC and SCC microdissected regions are shown in fig 1. Microdissected cells were collected in $5 \mu \mathrm{l}$ of a solution $(10 \mathrm{mM}$ Tris $/ \mathrm{HCl}$, $\mathrm{pH} 7.5,10 \mathrm{mM} \mathrm{NaCl}, 0.1 \%$ sodium dodecyl sulphate) containing $0.5 \mathrm{mg} / \mathrm{ml}$ proteinase $\mathrm{K}$. Samples were incubated for several hours in a moist chamber at $65^{\circ} \mathrm{C}$, followed by boiling for 10 minutes to inactivate the proteinase $\mathrm{K}$.

For each cellular subtype (cirrhotic, dysplastic foci, and HCC) at least two distinct samples were microdissected. Genomic DNA extracted from 30 peripheral blood lymphocytes of healthy donors was used as a source of normal DNA. Lymphocytes were fixed three times in a methanol/acetic acid solution (3/1), and stained by Giemsa.
DEGENERATE OLIGONUCLEOTIDE POLYMERASE CHAIN REACTION (DOP-PCR)

DOP-PCR was performed following two steps on a thermocycler (PTC-100, MJ Research, Watertown, Massachusetts, USA). Eight initial cycles (preamplification step) were carried out in a $6 \mu \mathrm{l}$ reaction volume $(200 \mu \mathrm{M}$ of each dNTP, 0.6× Sequenase buffer (Amersham, Cleveland, Ohio, USA), $5 \mu \mathrm{M}$ UN1 primer (5'CCG ACT CGA GNN NNN NAT GTG G-3')) with one minute at $96^{\circ} \mathrm{C}, 2.20$ minutes at $25^{\circ} \mathrm{C}$, and two minutes at $37^{\circ} \mathrm{C}$, with the addition of $0.4 \mathrm{U}$ of Sequenase version 2.0 (Amersham) at each of the $25^{\circ} \mathrm{C}$ steps. After this low stringency preamplification, 34 cycles were performed in a $50 \mu \mathrm{l}$ reaction volume (200mM dNTPs, $1 \mathrm{mM}$ UN1 primer, $2.5 \mathrm{mM}$ $\mathrm{MgCl}_{2}, 1 \times$ Stoffel buffer (Perkin-Elmer, Branchbury, New Jersey, USA), and $1 \mathrm{U}$ AmpliTaq DNA polymerase, Stoffel fragment (Perkin-Elmer)), with one minute at $94^{\circ} \mathrm{C}$, one minute at $56^{\circ} \mathrm{C}$, two minutes at $72^{\circ} \mathrm{C}$, and a final extension of 10 minutes at $72^{\circ} \mathrm{C}$.

DNA LABELLING

The DOP-PCR amplification products $(4 \mu \mathrm{l})$ were labelled by a third amplification step using $0.8 \mu \mathrm{l}$ of fluorescein 12-dUTP and $0.8 \mu \mathrm{l}$ of fluorescein 12-dCTP for test DNA or Texas red 5-dUTP and Texas red 5-dCTP for normal DNA in a $20 \mu 1$ reaction volume $(1 \times$ Replitherm buffer (Biozym, Amelyn, Germany), $2.5 \mathrm{mM}$ $\mathrm{MgCl}_{2}, 2.5 \mathrm{mM}$ dATP and dGTP, $1.25 \mathrm{mM}$ dTTP and dCTP, 2mM UN1 primer, and 0.6 U AmpliTaq DNA polymerase), with three minutes at $95^{\circ} \mathrm{C}$ followed by 25 cycles of one minute at $94^{\circ} \mathrm{C}$, one minute at $56^{\circ} \mathrm{C}$, two minutes at $72^{\circ} \mathrm{C}$, and a final extension of five minutes at $72^{\circ} \mathrm{C}$
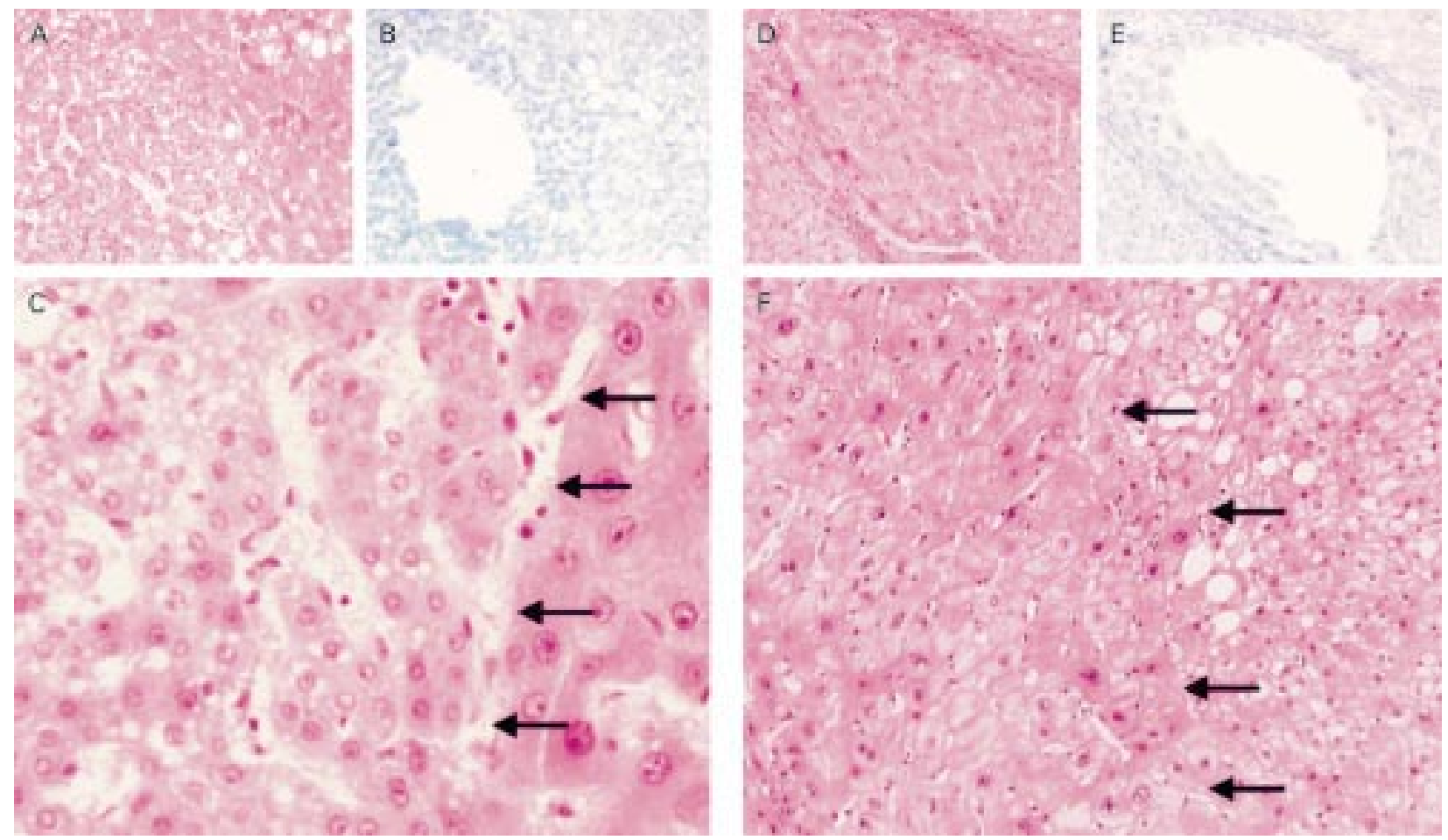

Figure 1 Serial tissue sections of samples with $(A, B)$ small cell changes (SCC) and $(D, E)$ large cell changes (LCC) after haematoxylin and eosin staining $(A, D)$ and the corresponding area after removal of the dysplasic cells of sections stained by Giemsa $(B, E)$. $(C)$ Higher magnification of an SCC sample $(\times 200)$ and $(F)$ an LCC sample ( $\times 100)$; the dysplastic areas are delimited by arrows. 
Table (T)

\begin{tabular}{|c|c|c|c|c|c|c|}
\hline Sample & Aeiology & Grade & Size $(\mathrm{cm})$ & & Gains & Losses \\
\hline \multirow[t]{3}{*}{$\mathrm{E} 2$} & \multirow[t]{3}{*}{ Haemochromatosis } & & & SSC & None & None \\
\hline & & & & LCC & None & None \\
\hline & & II & 2.5 & & $1 \mathrm{q}, 8 \mathrm{q}$ & $8 \mathrm{p}$ \\
\hline \multirow[t]{2}{*}{ E3 } & \multirow{2}{*}{$\mathrm{HBV}$} & & & SCC & $6 p, 8 q$ & \\
\hline & & II & 2 & $\mathrm{~T}$ & $1 \mathrm{q}, 2, \mathbf{6 p}, 8 \mathbf{q}$ & $4 \mathrm{q}, 8 \mathbf{p}$ \\
\hline \multirow[t]{2}{*}{ E7 } & \multirow[t]{2}{*}{$\mathrm{HBV}$} & & & LCC & None & None \\
\hline & & III & 7 & & $1 \mathrm{q}, 6 \mathrm{p}$ & None \\
\hline \multirow[t]{2}{*}{ E8 } & \multirow[t]{2}{*}{$\mathrm{HCV}$} & & & SCC & None & $10 q, 16,17 p$ \\
\hline & & I & 2 & & None & $4, \mathbf{1 0 q}, \mathbf{1 6}, \mathbf{1 7} \mathbf{p}$ \\
\hline E9 & HBV & III & 7 & $\begin{array}{l}\text { LCC } \\
\text { T }\end{array}$ & $\begin{array}{l}\text { None } \\
1 \mathrm{q}, 8 \mathrm{q} 22 \mathrm{qter}, 12 \mathrm{q}, 17 \mathrm{q}\end{array}$ & $\begin{array}{l}\text { None } \\
8 \mathfrak{p} 22 \mathrm{pter}, 12 \mathrm{p}, 16 \mathrm{q}, 17 \mathrm{p}\end{array}$ \\
\hline
\end{tabular}

Common abnormalities between liver cell dysplasias and tumours are in bold $\mathrm{HBV}$, hepatitis B virus; $\mathrm{HCV}$, hepatitis $\mathrm{C}$ virus.

COMPARATIVE GENOMIC HYBRIDISATION (CGH) Metaphase cells for CGH experiments were prepared from phytohaemagglutinin stimulated lymphocytes of healthy men. Lymphocyte cultures were synchronised by the thymidine method. ${ }^{18}$ The slides were hybridised for 72 hours with $20 \mu \mathrm{l}$ of DOP-PCR labelled DNA in the presence of $50 \mu \mathrm{l} \mathrm{Cot}-1$ DNA and $50 \mu \mathrm{g}$ of sonicated salmon sperm DNA. After hybridisation, the slides were washed for two minutes in $0.4 \times$ saline sodium citrate (SSC) at $74^{\circ} \mathrm{C}$ and one minute in $2 \times \mathrm{SSC} / 0.1 \% \mathrm{NP} 40$ at room temperature. DNA was counterstained with $0.2 \mathrm{mM}$ DAPI (4,5-diamino-2-phenylindole) in antifade solution.

DATA ACQUISITION AND PROCESSING

For each hybridisation, 10 metaphase cells were analysed using a Zeiss axioskop fluorescence microscope (Zeiss, Oberhochen, Federal Republic of Germany) and a Quips fish digital analysis system (Vysis, Illinois, USA) composed of a computer driven cooled CCD colour camera and Quips-XL software automated analysis software (Vysis). Relative changes in the copy number of DNA sequences were analysed using an adapted digital image analysis system. Chromosome regions were interpreted as over-represented if the corresponding colour ratio was higher than 1.25 and as under-represented if the ratio was lower than 0.75 .

The amounts of DOP-PCR product and labelled DNA used in the experiments were normalised by the comparative analysis of a classic CGH, with DNA obtained from a frozen tumour, and a DOP-CGH with DNA from the corresponding microdissected region of the same tumour. The DOP-PCR product of each microdissection was hybridised at least twice and associated with normal DNA from two different healthy donors.

\section{Results}

No abnormality was detected in the nine benign cirrhotic nodules analysed. Four of the nine HCCs and the corresponding dysplasias revealed no abnormalities by DOP-CGH. As shown in table 1, gains of chromosome arms 1q (four of nine) and 8q (three of nine) and loss of $8 p$ (three of nine) were the most frequent alterations seen in the tumours (for example,
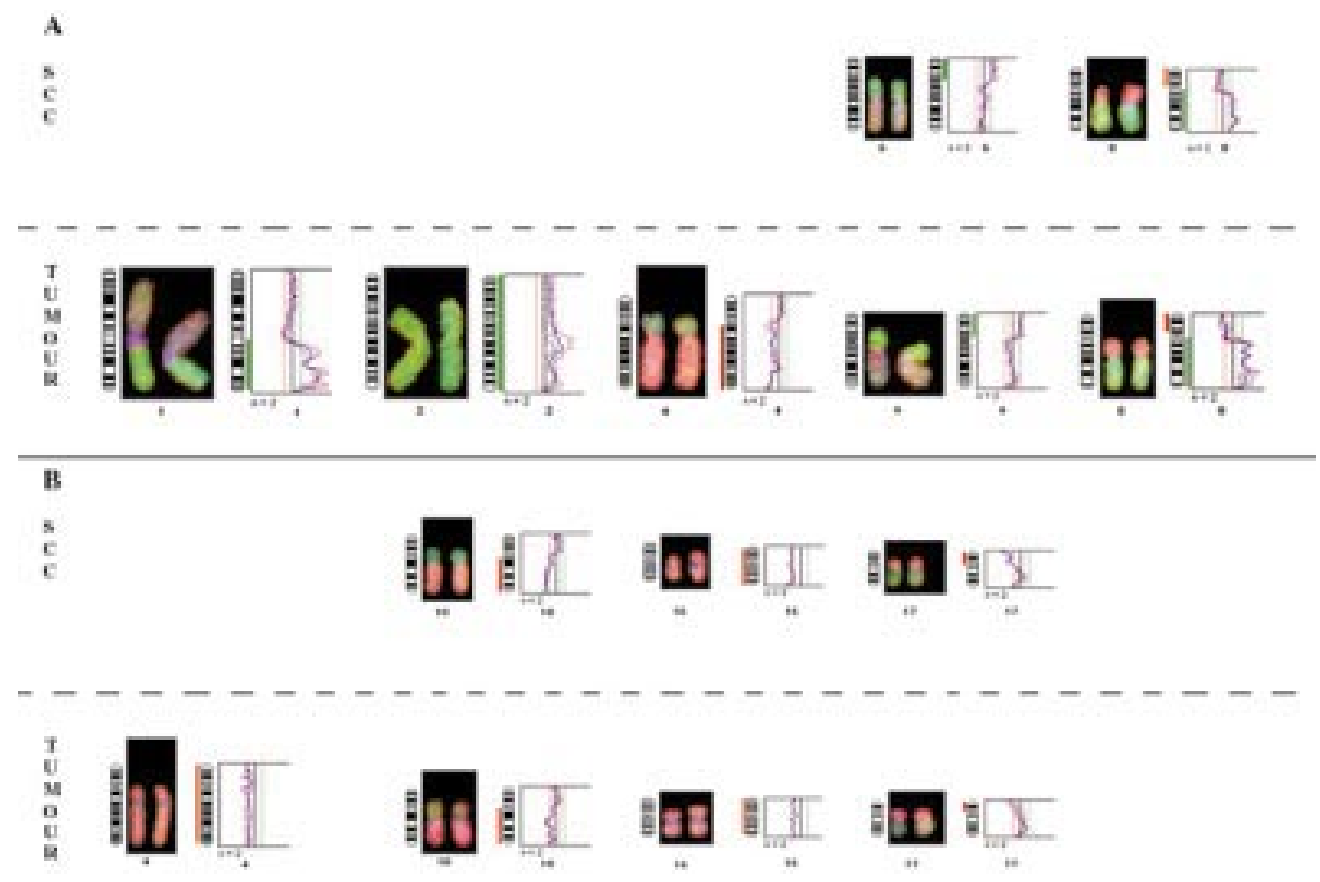

Figure 2 Chromosomal abnormality pattern found in small cell changes (SCC) and adjacent tumour of patients E3 (A) and $E 8(B)$. 
see fig 2). These results agree with previous data implicating these chromosomal imbalances as major abnormalities associated with HCC. ${ }^{19}{ }^{20}$ None of the LCC found with these tumours (E2, E7, and E9) revealed abnormalities. In contrast, two of the three SCC (E3 and E8 but not E2) exhibited a subset of the abnormalities found in the tumours. In the SCC from the HBV infected patient (E3), the loss of $8 p$ and gains of $6 p$ and $8 q$ were detected (table 1). Such genetic changes frequently found in full blown HCC are probably early events in tumour development. In contrast, other alterations highly prevalent in HCC, such as 1q gains or $4 \mathrm{q}$ losses, were not found in SCC. In the samples from the HCV infected patient (E8), three of the four abnormalities found in the tumour (losses of 10q, 16, and 17p) were also seen in the SCC.

\section{Discussion}

As with many other carcinomas, the development of HCC is characterised by an accumulation of genetic alterations. We and others have previously reported, either by molecular genetic studies ${ }^{21} 22$ or by $\mathrm{CGH},{ }^{20}$ the frequent loss of chromosomes $1 \mathrm{p}(30-40 \%), 4 \mathrm{q}(40-70 \%)$, $8 \mathrm{p}(30-65 \%), 16 \mathrm{q}(30-50 \%)$, and $17 \mathrm{p}(30$ $50 \%)$ and gains of chromosomes $1 \mathrm{q}(60-80 \%)$, $6 q(30-40 \%), 8 q(60-70 \%)$, and $17 q(30 \%)$. In many tissues, cell dysplasia is recognised as a precancerous lesion. However, the preneoplastic nature of liver cell dysplasia remains controversial because no genetic pathway has been established to link liver cell dysplasia to HCC. $^{23} 24$

Some authors consider LCC to be a regenerative or degenerative condition, ${ }^{16} 25$ whereas others have shown by prospective studies that LCC is an important risk factor for HCC. ${ }^{12}{ }^{13}$ Because of the lack of histological continuity between LCC and HCC, the comparison of their genetic abnormalities could be useful in providing evidence for the possible preneoplastic status of LCC. We have previously shown by interphase cytogenetic analysis that LCC are composed of polyploid cells. ${ }^{26}$ In our present study, none of the microdissected LCC foci revealed chromosomal imbalances even when the adjacent HCC displayed such alterations. Our results do not support a direct relation between LCC and HCC. The lack of relevant genetic abnormalities in LCC, combined with their multiploidy and low proliferation rates, suggests that the appearance of such cells could result from impaired DNA replication in hepatocytes, as previously suggested by Altmann. ${ }^{27}$ Thus, LCC might be a consequence of chronic injury in a subpopulation of terminally differentiated or "senile" hepatocytes of limited proliferative capacity, ${ }^{14}{ }^{15}$ and is therefore more likely to be a pericancerous marker, rather than a true precancerous lesion. ${ }^{28}$ Similarly, cirrhotic nodules, which could also be considered as precancerous lesions, failed to exhibit chromosome segment gains or losses in the nine specimens analysed, confirming previous observations. $^{2029}$
To date, there are no uniform criteria for defining SCC, a situation reflected by the broad variations in its detection by pathologists examining liver cirrhosis. In our study we defined SCC as a group of cells showing an "expansive pattern" with smaller amounts of cytoplasm than normal hepatocytes and an increased nuclear/cytoplasmic ratio (fig 1). However, these cytological and structural atypia are not sufficient to allow a definite diagnosis of well differentiated HCC (or grade I according to the Edmonson and Steiner criteria). ${ }^{17}$ Furthermore, such foci did not correspond to intrahepatic metastasis of the adjacent HCC, because in all cases with SCC the latter showed a moderately differentiated pattern. SCC has been reported to be a preneoplastic change because of its phenotypic similarities with well differentiated HCC and its higher incidence in cirrhotic livers bearing HCC. ${ }^{8}$ To date, however, no studies have attempted to identify genetic changes occurring in such cells. In two of the three foci of SCC analysed, we detected chromosomal alterations very similar to those present in the adjacent HCC. These results suggest that SCC is a preneoplastic lesion. In SCC, the absence of $1 \mathrm{q}$ amplification and $4 \mathrm{q}$ loss (the most frequent abormalities found in HCCs) suggests that these abnormalities are associated with tumour progression. Furthermore, loss of $8 \mathrm{p}$ and gain of $8 \mathrm{q}$ found in a SCC may correspond to earlier events. ${ }^{30}$ In contrast, losses of $16 \mathrm{q}$ and $17 \mathrm{p}$, reported to be linked to HBV infection, ${ }^{31}$ are present in SCC, suggesting an association of these abnormalities with tumour initiation. The loss of the $10 \mathrm{q}$ arm is a rare event in HCCs of non-B, non-C, and HBV infected patients, but is seen frequently in HCCs associated with $\mathrm{HCV}$ infection. ${ }^{32}$ Loss of $10 \mathrm{q}$ detected in the HCV associated SCC suggests an early involvement of this abnormality in HCV induced HCC.

Our study demonstrates that the combined approach of microdissection, DOP-PCR, and $\mathrm{CGH}$ is suitable to identify early genetic change in liver cell dysplasia. A recent report from Libbrecht et al showed that SCC and the putative liver progenitor cells, but not LCC, exhibit the same immunohistochemical phenotype. ${ }^{33}$ In addition, the presence of such progenitor cells in more than $60 \%$ of SCCs suggests that these cells can give rise to foci of SCC. Taken together, these results may lead to a consistent model of human hepatocarcinogenesis. Further molecular analysis of the putative progenitor cells contained in SCC should hopefully establish a genetic link between an individual cell type and HCC.

This work was supported by a grant from Association pour la Recherche sur le Cancer (ARC), la Ligue Nationale contre le Cancer, and the Societe Nationale Française de GastroentéroloPasteur-Weizman. We warmly thank J S Seeler for his careful reading of the manuscript.

1 Terminology of nodular hepatocellular lesions. International Working Party. Hepatology 1995;22:983-93.

2 Takayama T, Makuuchi M, Hirohashi S, et al. Malignant transformation of adenomatous hyperplasia to hepatocellular carcinoma. Lancet 1990;336:1150-3. 
3 Sakamoto S, Hirohashi S, Shimosato Y. Early stages of multistep hepatocarcinogenesis: adenomatous hyperplasia and

4 Kojiro M, Nakashima O. Histopathologic evaluation of hepatocellular carcinoma with special reference to smal early stage tumours. Semin Liver Dis 1999;19:287-96.

5 Le Bail B, Belleannee G, Bernard P, et al. Adenomatous hyperplasia in cirrhotic livers: histological evaluation, cellular density, and proliferative activity of 35 macronodular lesions in the cirrhotic explants of 10 adult French patients. Hum Pathol 1995;26:897-906.

6 Ferrell L, Crawford J, Dhillon A, et al. Proposal for standardized criteria for the diagnosis of benign, borderline, and malignant hepatocellular lesions arising in chronic advanced liver disease. Am F Surg Pathol 1993;17:1113-23.

7 Anthony P, Vogel C, Baker L. Liver cell dysplasia: a premalignant condition. $f$ Clin Pathol 1973;26:217-23.

8 Watanabe S, Okita K, Harada T, et al. Morphologic studies of the liver cell dysplasia. Cancer 1983;51:2197-205.

9 Roncalli M, Borzio M, DeBiagi G, et al. Liver cell dysplasia in cirrhosis: a serologic and immunohistochemical study. in cirrhosis: a serologic and

10 Akagi G, Furuya K, Kanamura A, et al. Liver cell dysplasia and hepatitis B surface antigen in liver cirrhosis and hepatocellular carcinoma. Cancer 1984;54:315-18.

11 Le Bail B, Bernard P, Carles J, et al. Prevalence of liver cell dysplasia and association with HCC in a series of 100 cirrhotic liver explants. F Hepatol 1997;27:835-42.

12 Borzio M, Bruno S, Roncalli M, et al. Liver cell dysplasia is a major risk factor for hepatocellular carcinoma in cirrhosis: a prospective study. Gastroenterology 1995;108 812-17.

13 Ganne-Carrié N, Chastang C, Chapel F, et al. Predictive score for the development of hepatocellular carcinoma and additional value of liver large cell dysplasia in Western patients with cirrhosis. Hepatology 1996;23:1112-18.

14 Lee R, Tsamandas A, Demetris A. Large cell change (liver cell dysplasia) and hepatocellular carcinoma in cirrhosis: matched case-control study, pathological analysis, and matched case-control study, pathological analysis, and

15 Borzio M, Roncalli M, Trere D, et al. Preneoplastic cellular changes in liver. Hepatology 1998;28:1435.

16 Cohen C, Berson S. Liver cell dysplasia in normal, cirrhotic and hepatocellular carcinoma patients. Cancer 1986;57: $1535-8$

17 Edmonson H, Steiner P. Primary carcinoma in the liver. A study of 100 cases among 48900 necropsies. Cancer 1954 7:462-503.

18 Viegas-Péquignot E, Dutrillaux B. Une méthode simple pour obtenir des prophases et des prométaphases. Ann Genet 1978;21:122-4.
19 Marchio A, Meddeb M, Pineau P, et al. Recurrent chromosomal abnormalities in hepatocellular carcinoma. Genes Chromosomes Cancer 1997;18:59-65.

20 Wong N, Lai P, Lee SW, et al. Assessment of genetic changes in hepatocellular carcinoma by comparative genomic hybridization analysis. Am f Pathol 1999;154:37-43.

21 Nagai H, Pineau P, Tiollais $\mathrm{P}$, et al. Comprehensive allelotyping of human hepatocellular carcinoma. Oncogene 1997; 14:2927-33.

22 Boige V, Laurent-Puig P, Fouchet P, et al. Concerted nonsyntenic allelic losses in hyperploid hepatocellular carcinoma as determined by a high resolution allelotype. Cancer Res 1997;57:1986-90.

23 Roncalli M, Borzio M, Brando B, et al. Abnormal DNA content in liver-cell dysplasia: a flow cytometric study. Int $\mathcal{f}$ Cancer 1989;44:204-7.

24 Rubin E, De Rose P, Cohen C. Comparative image cytometric DNA ploidy of liver cell dysplasia an
hepatocellular carcinoma. Mod Pathol 1994;7:677-80.

25 Henmi A, Uchida T, Shikata T. Karyometric analysis of liver cell dysplasia and hepatocellular carcinoma. Evidence against precancerous nature of liver cell dysplasia. Cancer 1985;55:2594-9.

26 Terris B, Ingster O, Rubbia L, et al. Interphase cytogenetic analysis reveals numerical chromosome aberrations in large liver cell dysplasia. F Hepatol 1997;27:313-19.

27 Altmann H. Hepatic neoformations. Pathol Res Pract 1994;190:513-17.

28 Scoazec J. Dysplasie hépatocytaire: lésion pré- ou péricancéreuse? Gastroenterol Clin Biol 1999;23:433-7.

29 Nishida N, Fukuda Y, Kokuryu H, et al. Accumulation of allelic loss on arms of chromosomes 13q, 16q and $17 \mathrm{p}$ in the advanced stages of human hepatocellular carcinoma. Int 7 Cancer 1992;51:862-8.

30 Mertens F, Johansson B, Mitelman F. Isochromosomes in neoplasia. Genes Chromosomes Cancer 1994;10:221-30.

31 Marchio A, Pineau P, Meddeb M, et al. Distinct chromosomal abnormality pattern in primary liver cancer of non-B, non-C patients. Oncogene 2000;19:3733-8.

32 Kusano N, Shiraishi K, Kubo K, et al. Genetic aberrations detected by comparative genomic hybridization in hepatocellular carcinomas: their relationship to clinicopathological features. Hepatology 1999;29:1858-62.

33 Libbrecht L, Desmet V, Van Damme B, et al. The immunochemical phenotype of dysplastic foci in human liver: correlation with putative progenitor cells. I Hepatol 2000;33:76-84 